\title{
Parental Involvement Moderates the Interrelationship between Stressful Events and Adolescents' Mental Health
}

\author{
1 Anastasia Ukhanova \\ 1 Department of Clinical Psychology, \\ Odessa I.I. Mechnikov National University.
}

\begin{abstract}
\end{abstract}
This is an empirical cross-sectional study designed to investigate the possible moderating role of parental involvement in the interaction between negative stressful life events in adolescents and their psychological well-being. As a part of the Swedish-Ukrainian initiative based on the SEYLE project strategy, 589 students from ten schools in the city of Odessa were questioned. The respondents' average age was 14.87 years (SD = 1.11 years). The study showed that high parental involvement plays a protective role regarding general and mental health, psychosomatic disorders, and Internet addiction in the respondents exposed to different stressful situations. Nevertheless, regarding several stressful events, high parental involvement appeared to have a negative effect. In particular, it was noticed in cases as being incarcerated $(F=6.80 ; P<0.01 ; \eta 2=0.01$; $\mathrm{B}=-0.93, \mathrm{Cl}-1.64--0.23)$, in case of a misdemeanour $(\mathrm{F}$ $=11.96 ; \mathrm{P}<0.001 ; \eta 2=0.02 ; \mathrm{B}=-0.83, \mathrm{Cl}-1.30--0.36)$, and in case of a traumatic injury or illness $(\mathrm{F}=5.40 ; \mathrm{P}<$ $0.05 ; \eta 2=0.01 ; \mathrm{B}=-0.54, \mathrm{Cl}-1.00--0.08)$. Thus, parental involvement, in general, has a protective effect on the mental health and psychological well-being of adolescents in most stressful situations. On the other hand, in some stressful situations, high parental involvement may have a negative impact on well-being outcomes, possibly due to negative emotional reactions of youngsters in situations which they would prefer to hide from their parents.
Keywords: adolescents, parental involvement, moderation, negative stressful life events, mental health

Article received: 29.08.2016.

Article accepted: 15.10.2017.

DOI: $10.24141 / 1 / 3 / 2 / 5$

Author for correspondence:

Anastasia Ukhanova, Senior Lecturer of the Department of Clinical Psychology, Odessa I.I. Mechnikov National University. email: pestrueva@ukr.net

Phone: +380503338848

Address: Odessa, Pedagogicheskiy lane 3/1, fl. 13. 


\section{Introduction}

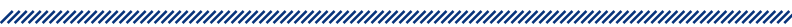

Communication with parents is one of the important family's resources for maintaining general health, as well as mental health and well-being of adolescents. It is supposed to promote the development of social values that equip the younger generation with the ability to cope with stressful situations and can protect them from adverse social and psychological influences [1]. Since L. Steinberg and S. Georgiou published their first works on parental involvement and suggested measurable signs of it, this problem took a firm stand in the psychological, educational, medical and sociological studies [2,3]. On the other hand, the concept of parental involvement is still under development. For instance, Georgiou considers that it is used too loosely and suggests more specific behavioural indicators, rather than such indefinite term [2]. We examined the work of a number of authors and understand parental involvement as a set of parental beliefs, attitudes and practical actions, ranging from understanding where the child is at the moment [4] and being acquainted with his friends [2] to parental beliefs that that they should be actively involved in the education of their children [5], as well as conveying to children a sense of patriotism [6], promoting hopes in the future [7], and being open to suggestions to interact that are coming from schools, teachers and children themselves [8]. Our basis is the opinion of McNeal, who argued that different types (variants) of parenting patterns may have different effects on children's cognitive and behavioural outcomes [9].

In the contemporary realities in Ukraine, the issue of parental involvement and its role in the mental health and well-being of youngsters has become increasingly important. It looks very probable that in the period of social and economic instability when parents are forced to give priority to financial issues and family survival, many parents are unable to devote enough time to their children. The majority of recent studies of parental involvement discuss the role of this family characteristic in relation to the academic performance of adolescents $[10,11,12$, $13,14,15,16]$, including possible moderating effect [17]. Another direction of studies is the evaluation of its role as a protective factor regarding negative lifestyles [18] though its moderating role regarding the mental health of children has not been evaluated. High parental involvement is also seen as a source of emotional support to adolescents in difficult life situations [19]. On the other hand, since adolescents are ambivalent, still attached to their parents and already building pathways to their autonomy, it may be hypothesized that high parental involvement (often perceived as parental control) may have differential effects in stressful situations experienced by adolescents. For instance, overprotective parents may not promote such qualities as autonomy and assertion in their children and hence, they may become easy targets for peers' victimization [20].

In this particular study, we are addressing the following questions:

1. Can parental involvement be protective against negative influence of stressful events on the mental health of adolescents?

2. Is it possible to evaluate the moderation effect of parental involvement on the associations between stressful events and adolescents' mental health using regression models?

Thus, the following hypothesis of study has been formulated: parental involvement can moderate the interrelationship between stressful events and the mental health of adolescents with both positive and negative effects. Consequently, the purpose of this study was to investigate the role of parental involvement as a moderator of the influence of stressful events on teenagers' mental health.

\section{Methods and contingents}

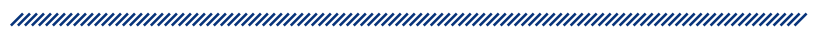

The study was carried out at the secondary schools in the city of Odessa. 589 teenagers participated in the survey. The respondents' average age was 14.87 years ( $S D=1.11$ years). The work was performed as part of the Swedish-Ukrainian project on the study of adolescents' mental health (headed by Prof. V. Rozanov) in collaboration with the Swedish National Centre of Suicide Research (headed by Prof. D. Wasserman), with the support of the Swedish Institute.

Inclusion criteria were Ukrainian adolescents from Odessa aged between 12 and 18 years. The total sample of the study was 615 people. However, after exclusion of 26 compromised records, the final sample included 589 subjects.

The survey was carried out after the teaching staff and the parent committees were informed, in coordination 
with school authorities and with the assistance of school psychologists. School children were informed about the goals of the survey, which was organized as part of ongoing psychological testing that is usually carried out according to existing school plans. During and after the survey, psychological aid and counselling opportunities were suggested (by mobile phone, by email or on the interviewer psychologist's social network page).

The methodological basis of the study was the Comprehensive Questionnaire on Mental Health and Personality Lifestyle, developed to reach the objectives of the European research SEYLE (Saving and Empowering Young Lives in Europe) [21]. This study is a continuation of research works [22, 23, 24], carried out as part of the study of adolescents' mental health.

The study examined the following parameters within the SEYLE questionnaire: the current state of health, the presence of psychosomatic symptoms, the total score on the Beck Depression Scale $(\alpha=0.856)$, the WHO well-being scale $(\alpha=0.779)$, the Stressful Events Scale $(\alpha=0.700)$, the Scale of Internet Addiction in Teenagers $(\alpha=0.663)$, and the Scale of Parental Involvement $(\alpha=0.738)$. The last three scales were adapted by the author.

\section{Stressful Events Scale}

The scale has 26 items about stressful (negative) events experienced in the last six months. For example: "Failed important examination", "Sex problems", "Jail term" etc. The dichotomous scale was used for answers (yes/no).

\section{Beck Depression Scale}

The scale is composed of 21 items that evaluate the severity of depression. Each question deals with the respondent's particular symptoms and changes in mood over the last two weeks, with a 4-point scale. The degree of depression is indicated by the total score [25].

\section{WHO well-being scale}

The WHO well-being scale is an inventory that focuses on the topic of health for all [26].

\section{Scale of Internet Addiction in Teenagers}

The scale has 8 items extracted from the well-known Internet Addiction scale by K. Young [27]. For example: "Do you feel you are totally involved in the Internet?", "Are you online longer than planned?" etc. The dichotomous scale was used for answers (yes/no).

\section{Scale of Parental Involvement (from the SEYLE composite questionnaire)}

The scale has 7 items. For example: "How often do your parents check your homework?" or "How often do your parents understand your problems?" etc. The 5-score Likert scale was used for answers.

We focused on the investigation of moderation effects, which implies the following principles. A moderator variable specifies when or under what conditions a predictor variable influences a dependent variable $[28,29]$. A moderator variable may reduce or enhance the direction of the relationship between a predictor variable and a dependent variable, or it may even change the direction of the relationship between the two variables from positive to negative, or vice versa [30]. A moderating effect can be considered when the relationship between a predictor variable and a dependent variable is strong, but most often it is considered when there is an unexpectedly weak or inconsistent relationship between a predictor and a dependent variable $[28,29]$. The moderating effect is typically expressed as an interaction between a predictor and moderator variable $[28$, 29, 31].

\section{The data analysis section}

We investigated the impact of parental involvement on the interrelations between stressful events in teenagers' lives and the aforementioned parameters of the questionnaire. The main statistical method was the moderation analysis. For moderation analysis, we used R. M. Baron `s and D.A. Kenny 's understanding of it. They say that a moderator is a qualitative (e.g., sex, race, class) or quantitative (e.g., level of reward) variable that affects the direction and/or strength of the relation between an independent or predictor variable and a dependent or criterion variable [28]. "Moderation analysis" used to examine how the effect of an antecedent $X$ on a consequent $Y$ depends on a third moderator variable $M$ ("interaction"). The effect of $X$ on $Y$ can be said to be moderated if its size or direction is dependent on M. It tells us about the conditions that facilitate, enhance, or inhibit the effect, or for whom or what the effect is large vs. small, present vs. absent, and so forth. Moderation $\mathrm{M}$ is depicted here to moderate the size of 
the effect of $X$ on $Y$, meaning that the size of the effect of $X$ on $Y$ depends on $M$. We say $M$ is the moderator of the $X \rightarrow Y$ relationship, or $X$ and $M$ interact in their influence on $Y$ [32]. In each analysis, the following formal indices were obtained: $\mathrm{F}$ ( $\mathrm{F}$-test); $\mathrm{p}$ (its $\mathrm{p}$-level); $\eta 2$ (Eta squared); $\mathrm{B}$ (regression coefficient) and $\mathrm{Cl}$ (95\% confidence interval) [28].

The data processing was performed using the software package IBM SPSS Statistics 22.0.0.

\section{Results}

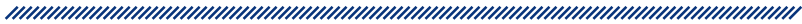

In the first stage of the study, we analysed descriptive statistics of parameters and the frequency of stressful events during the last 6 months in adolescents.

According to the protocol, 27 possible stressful events were suggested in the questionnaire and adolescents had to mark which happened to them in the last 6 months from that list. The frequency of experienced events is presented in Figure 1. As shown in the figure, the most frequent event was increased workload at school. The second highest rate belonged to the change in a health status of a family member. The third place was occupied by getting lower grades than expected, which also concerned school. Events which followed by frequency were related to conflicts and family problems. The last three places in the ranking belonged to such items as trouble with bullying, death of a close friend and pregnancy.

Proceeding from our model (Fig. 2), stressful events may have been associated with the adolescents' psychological well-being. In turn, the parental involvement can change this association, making it stronger or weaker.

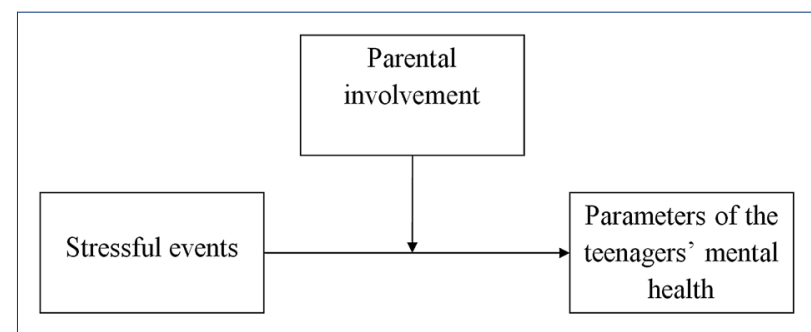

Figure 2. The model of the moderating effect of parental involvement on the association between stressful events with adolescents' mental health

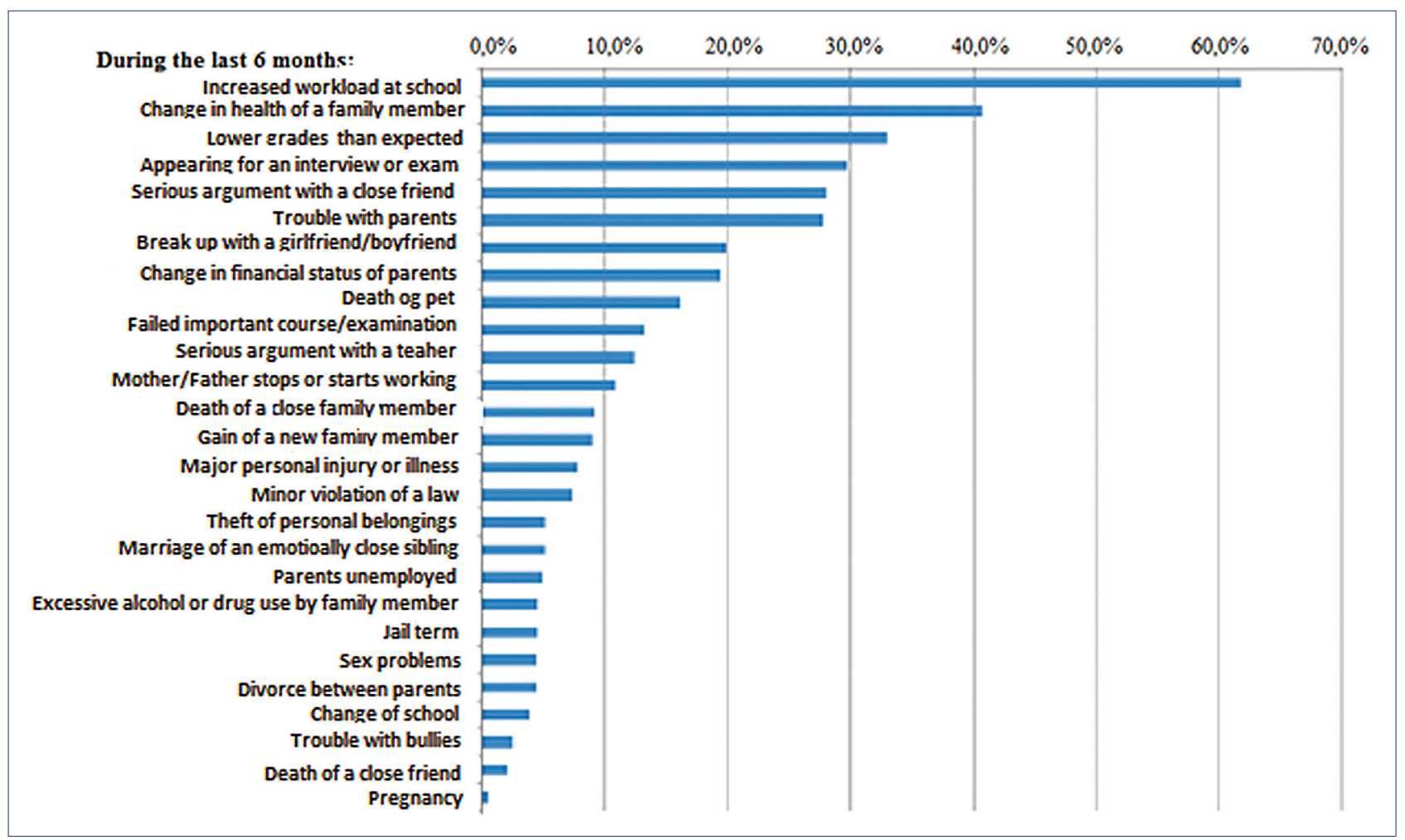

Figure 1. The frequency of stressful events in adolescents during the last 6 months 
In the second stage of the study, we tried to reveal the moderating effect of parental involvement. With regards to the existing model, parental involvement effects were studied regarding interaction of all stressful events with all indices of mental health selected for this study. Only statistically significant moderating effects $(p<0.05)$ are presented. Respondents that mentioned "trouble with parents" as a stressful event were also included in the analysis. However, moderating effects of parental involvement on the mental health of teenagers who experienced this stressful event were not found.

When we used the severity of the psychosomatic symptoms as the criterion variable, the moderating effect of parental involvement was found only for one stressful event -an exam or an interview. It was associated with psychosomatic symptoms in those who indicated a low level of parental involvement ( $F=7.33$; $P \leq 0.01 ; \eta 2$ $=0.015 ; \mathrm{B}=-0.61[\mathrm{Cl}-1.06--0.17])$. On the other hand, it was not associated with the state of health in adolescents with a high level of parental involvement in their life (Fig. 3). Thus, high parental involvement may be protective against psychosomatic consequences associated with academic stress.

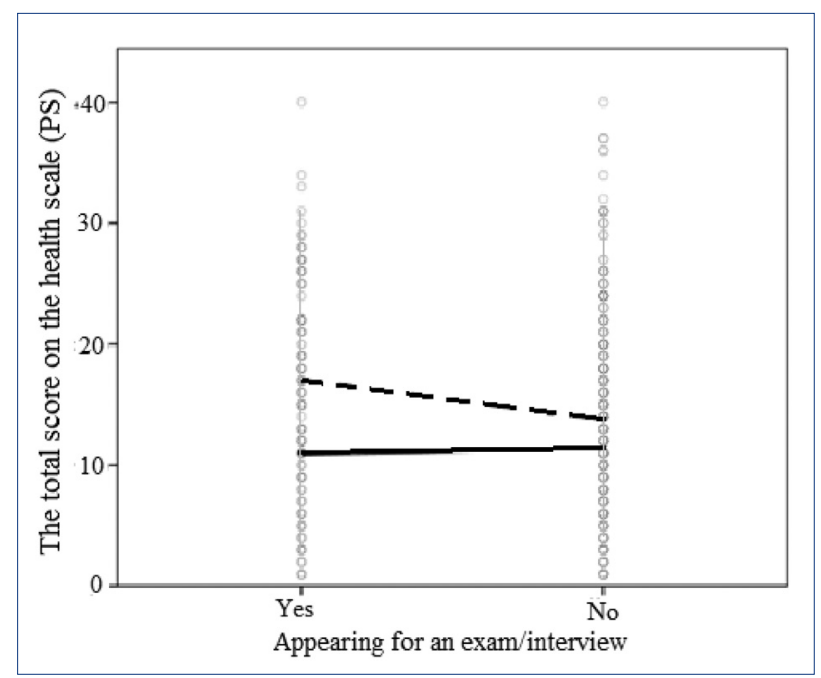

Figure 3. The moderating effect of parental involvement on the interrelations between a stressful event, such as an important interview or exam, and psychosomatic disorders in adolescents

Note (here and further): The full line shows a high level of parental involvement, while the interrupted line refers to a low level of parental involvement.
Adolescents' psychological well-being is an important sign of their general and mental health. It gave a statistically verified response in our analysis. However, the result was paradoxical. The negative moderating effect of parental involvement was established regarding some stressful events. For instance, jail term was not associated with the respondents' well-being if the extent of parental involvement in their life was low (Fig. 4). However, if the level of parental involvement was high, the same event appeared to be associated with lower subjective well-being $\left(F=6.80 ; P<0.01 ; \eta^{2}=0.013 ; B=-0.93\right.$ $[\mathrm{Cl}-1.64--0.230])$.

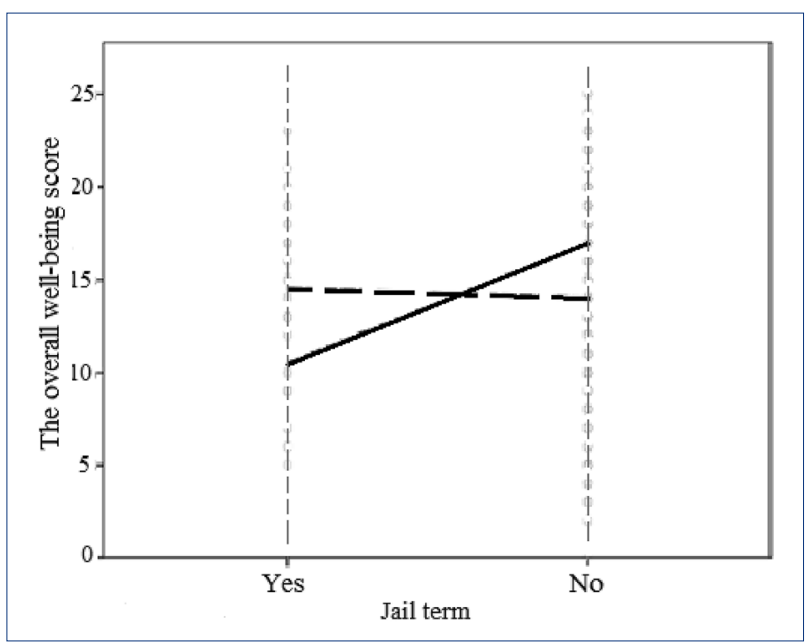

Figure 4. The moderating effect of parental involvement on the interrelations between a stressful event, such as a jail term, and the state of adolescents' subjective well-being

When the overall subjective well-being score was used as a criterion variable, the moderating effects of parental involvement were also found for four other events. Among the respondents who committed a minor violation of law, the level of subjective well-being was higher in case of a low level of parental involvement $(F=11.96$; $\left.\mathrm{P}<0.001 ; \eta^{2}=0.02 ; \mathrm{B}=-0.83[\mathrm{Cl}-1.30--0.36]\right)$. Conversely, children who did not violate a law felt better when the extent of parental involvement was high (Fig. 5).

Factors such as having a physical injury, or a somatic illness had almost no association with the subjective well-being in adolescents who reported low levels of parental involvement (Fig. 6). If the level of parental involvement in the schoolchildren's life was high, the teenagers who suffered from an injury or illness felt worse $\left(F=5.40 ; P<0.05 ; \eta^{2}=0.01 ; B=-0.54[C l-1.00-\right.$ $-0.08])$. 


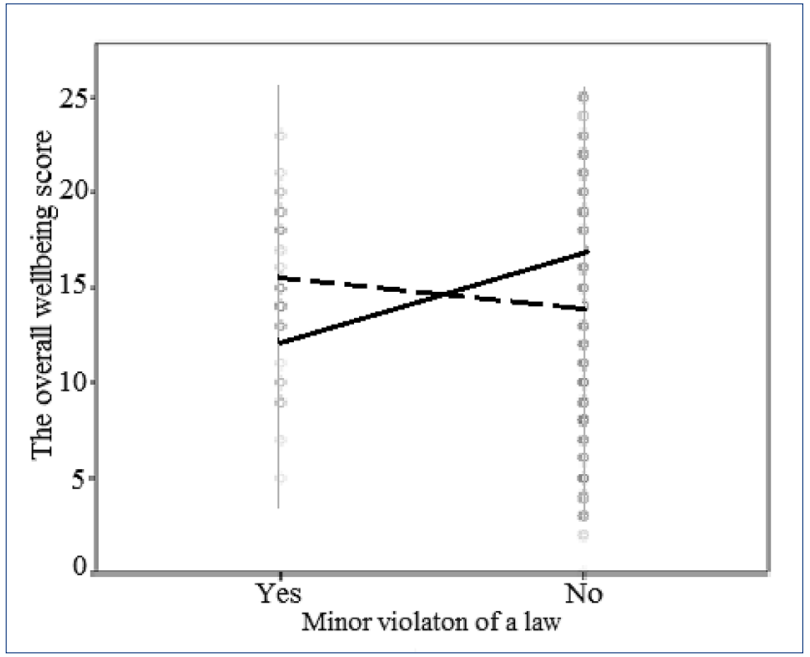

Figure 5. The moderating effect of parental involvement on the interrelations between a stressful event, such as minor violation of law, and the state of adolescents' subjective well-being

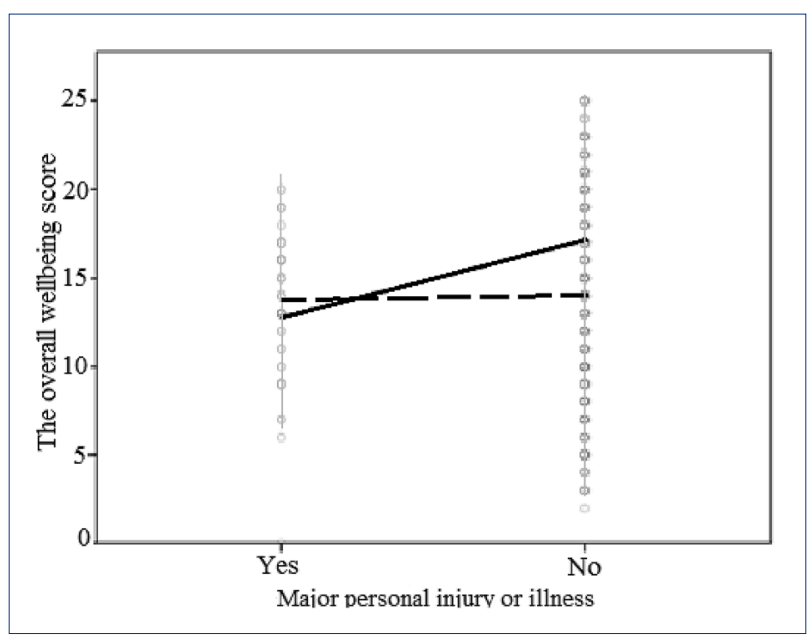

Figure 6. The moderating effect of parental involvement on the interrelations between a stressful event, such as an injury or illness, and the state of adolescent's subjective well-being

The divorce of parents is known to be seriously stressful for children and adolescents. However, if the level of parental involvement is low, the subjective well-being shows no significant association with the divorce of parents $\left(F=7.07 ; P<0.01 ; \eta^{2}=0.01 ; B=-0.87[C l-1.52-0.23]\right)$. On the contrary, when the level of parental involvement is high, the subjective well-being of students is more strongly impaired by their parents' divorce (Figure 7.).

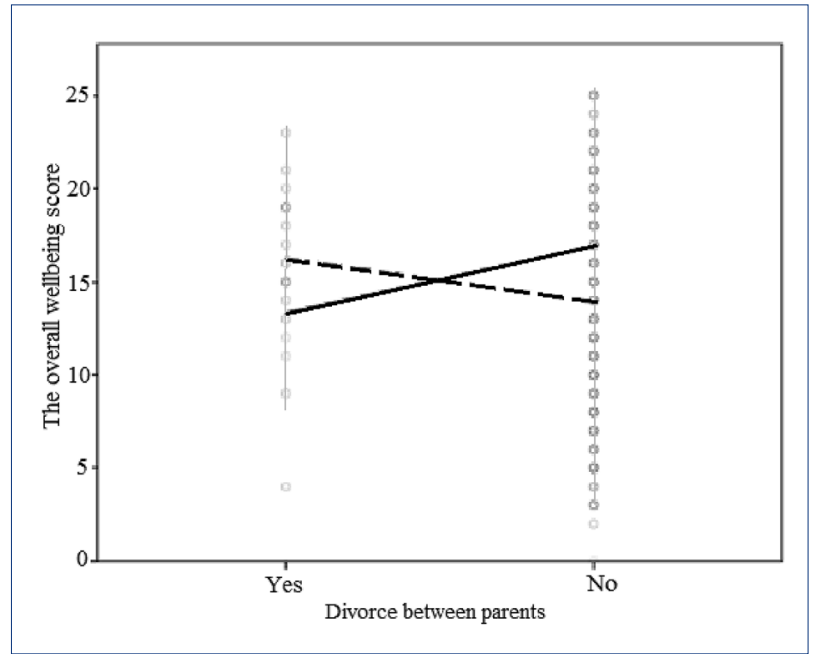

Figure 7. The moderating effect of parental involvement on the interrelations between a stressful event, such as a parents' divorce, and the state of adolescents' subjective well-being

So, we found the moderating effect of parental involvement on the interrelations between some stressful events in the lives of adolescents and their subjective well-being. In the next research stage, we analysed how parental involvement can affect the relationship between stressful events and symptoms of depression. No statistically significant moderating effects of parental involvement for the association with any stressful event on the Beck Depression Scale were found. Such stressful event as changes in the parents' financial status had the strongest association, but it was not statistically significant $\left(\mathrm{F}=3.52 ; \mathrm{P}=0.06 ; \eta^{2}=0.007 ; \mathrm{B}=0.54[\mathrm{Cl}\right.$ $-0.025-1.11])$.

Finally, we examined the effect of parental involvement on the interrelations between stressful events and Internet addiction in adolescents. Internet addiction is known to be a sign of poor mental health, which is often enhanced in stressful situations. It was found that Internet addiction was reduced in the respondents who indicated an event, such as being bullied, if their parents were strongly involved in their children's lives ( $F$ $=4.54 ; \mathrm{P}<0.05 ; \eta^{2}=0.008 ; \mathrm{B}=-0.32[\mathrm{Cl}-0.61--0.03]$ ). If the degree of parental involvement was low, the rate of Internet addiction in students under stress remained unchanged (Figure 8).

High parental involvement also attenuated Internet addiction in teenagers when they experienced an event, such as parents' divorce $\left(F=5.84 ; P<0.05 ; \eta^{2}=0.01 ; B\right.$ $=-0.28$ [Cl $-0.52--0.05]$ ) (Fig. 9). 


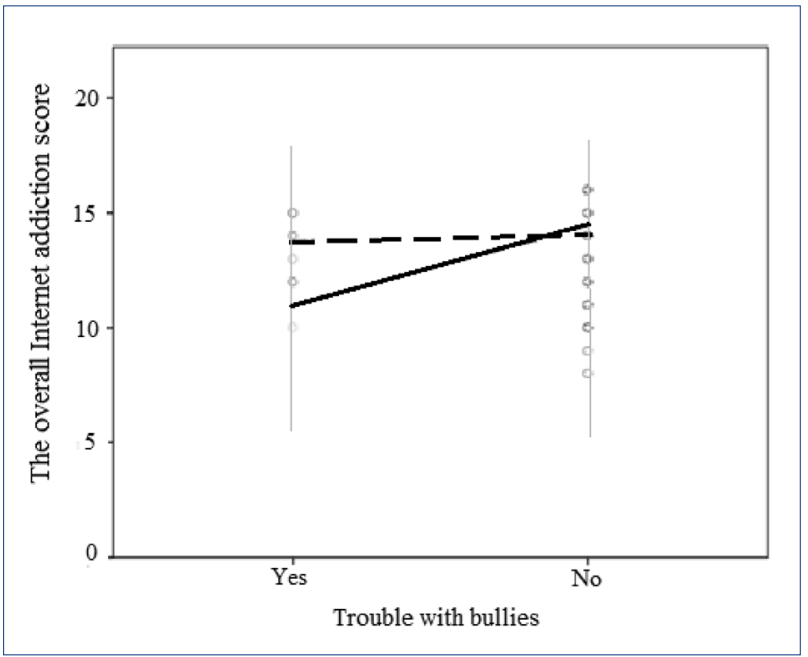

Figure 8. The moderating effect of parental involvement on the interrelations between a stressful event, such as being bullied, and the adolescent's Internet addiction

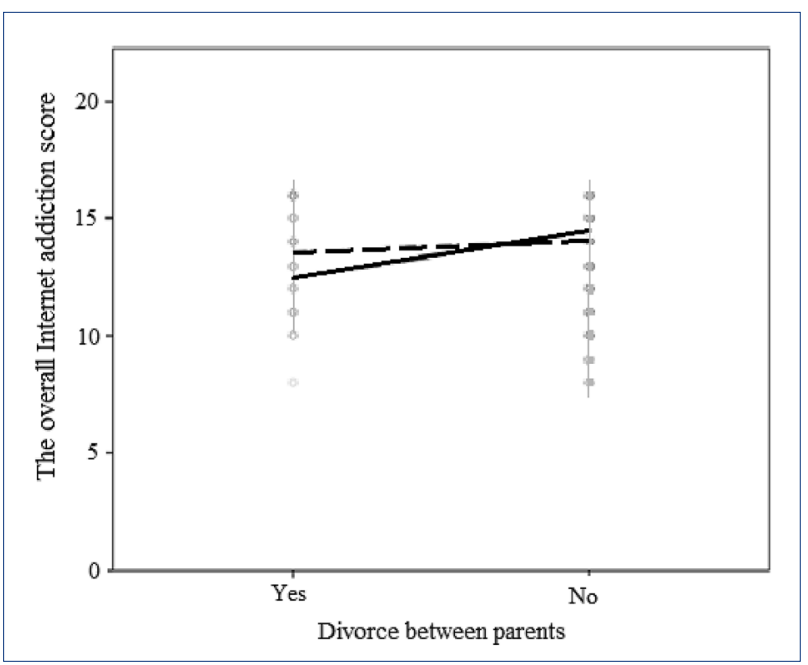

Figure 9. The moderating effect of parental involvement on the interrelations between a stressful life event, such as the parents' divorce, and the adolescent's Internet addiction

\section{Discussion}

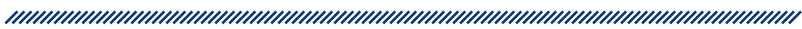

In this paper, we characterized the moderating effects of parental involvement in relation to the "stressor - adolescents' mental health" associations. To our knowledge, there is not enough information regarding the estimation of the role of parental involvement on the interrelationship between stressful events and adolescents' psychological well-being in Ukraine. The analysis of Ukrainian sources showed that, when this relation is discussed, authors were referring to international experience. For instance, L. Gutsulyak discussed the development of partnership and family using examples from the United States [33]. His paper presented sufficient evidence that parental involvement was a very effective educational tool that promoted academic performance of children. In another paper, A. Kovalchuk [34] described the role of parental involvement on the example of Western Europe. The data discussed were obtained during the implementation of autonomous school management programs (SBM). In her work, the author pointed out that parental involvement was one of the most powerful sources of success in school management. Parents can urge their children to do homework, show them the family's interest in the results of their studies, and participate in the organization of school work in the children's best interests.

Although the data obtained in our study do not have direct analogies in the literature we reviewed, we can draw a parallel with the trends that were identified by other authors who studied the same phenomenon. Adolescents (even those who belong to older age groups) who report that it is easy for them to communicate with their parents have higher self-esteem [1], higher level of satisfaction with life [35], and have fewer somatic and psychological complaints [36]. The literature sources also mention correlations between psychosomatic complaints and family conflicts, bullying, lack of acceptance by peers, and lack of support of parents and teachers [37]. If the family relations are positive, better health is consistently observed in adolescents [38], whereas in stressful family situations, children often develop serious health problems $[39,40]$. Thus, these studies confirm the protective potential of parent involvement in the mental health and psychological well-being. On the other hand, from a purely theoretical point of view, they often do not provide any persuasive evidence on the nature of effects of parental involvement - modulating or moderating existing associations. 
In our study, we concentrated on moderating effects of parental involvement. In general, this important family phenomenon acts as a protective factor against mental health problems in adolescents who reported stressful events in the past 6 months. A moderation analysis based on a special mathematical procedure revealed its positive role in several stressful situations that are able to impair adolescents' psychological well-being. For instance, high parental involvement attenuates negative effects of common factors, such as academic stress, bullying/victimization and parents' divorce (with some specific features depending on the nature of the variable that gives an impression regarding psychological well-being).

However, when the respondents encountered stressful events, such as being taken to a police department, committing a minor offense or suffering an injury, parental involvement acted as a negative factor and was associated with the worsening of the adolescents' subjective well-being. Thus, the use of models of moderation revealed that parental involvement does not always exert a positive effect on the adolescents' mental health. It is worth saying that information on the negative role of parental involvement can also be found in the literature. Some studies suggest that if parents are constantly involved in their children's homework preparation or excessively control their child's circle of friends, this can have a negative effect on school performance $[41,42,43]$.

The clinical significance of our study is that moderating role of parental involvement can be used in social school adjustment to prevent mental health problems, alcohol, cigarette, internet and drug abuse, suicidal and self-harm manifestations and depression. The practical significance of this study is an opportunity to discuss the ambivalent effect of parental involvement with teachers and with parents.

\section{Conclusion}

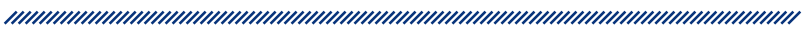

In the study of Ukrainian teenagers, we investigated the influence of parental involvement on the interrelations between stressful events in students' lives and their mental health. We analysed the frequency of occurrence of stressful events in the past 6 months in adolescents. In the first three places, according to frequency, were stressful events, such as an increase in the academic load at school, a family member's illness and getting worse grades than expected. The last three places in the ranking of the prevalence of stressful events belonged to items, such as bullying or persecution, death of a close friend and pregnancy. We studied the effect of parental involvement on the relations between stressful events in adolescents' lives and the following parameters of the SEYLE questionnaire: the current subjective well-being, the presence of psychosomatic disorders, the total score on the Beck Depression Scale and the level of Internet addiction in teenagers. The study found that parental involvement in most cases had a positive association with the mental health of teenagers who faced stressful situations during the last 6 months. The parameters of mental health in our study included questions relating to subjective well-being, psychosomatic disorders and Internet addiction in adolescents. However, for some parameters, we found a negative role of parental involvement. It was found that in the cases involving the police a high level of parental involvement was associated with the worsening of teenagers' subjective well-being. It was also found that children who suffered from an injury felt worse if the level of parental involvement was high. Thus, the use of moderation models revealed that parental involvement does not always have a positive effect on adolescents' mental health. The results of this study can be used in educational and psychological practice for the purposes of formation of healthy behaviours in adolescents.

\section{Study limitations}

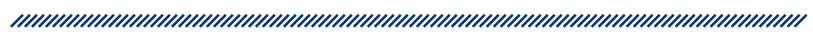

The study findings are limited by narrow geography of interviews conducted. Although the findings cannot be generalized across settings, they do provoke a new way of looking at the moderation role of parental involvement on the interrelationship between stressful events and the mental health of adolescents - not only in a positive, but also in a negative way. 


\section{References}

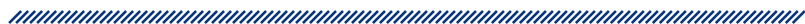

3. Currie C, Zanotti C, Morgan A, Currie D, de Looze M, Roberts $C$, et al., editors. Health Behaviour in School-aged Children (HBSC) study. International report from the 2009/2010 survey. Copenhagen: WHO Regional Office for Europe; 2012 [pristupljeno 07.07.2015.]. Dostupno na: http://www.euro.who. int/_data/assets/pdf_file/0003/163857/Social-determinants-of-health-and-well-being-among-young-people.pdf

4. Georgiou SN. Parental involvement: Definitions and outcomes. Soc Psychol Educ. 1996;1(3):189-209.

5. Steinberg L. Impact of parenting practices on adolescent achievement: authoritative parenting, school involvement, and encouragement to succeed. Child Dev. 1992;63(5):1266-1281.

6. Grolnick WS, Slowiaczek ML. Parents' involvement in children's schooling: a multidimensional conceptualization and motivational model. Child Dev. 1994;65(1):237-252.

7. Grolnick WS, Benjet C, Kurowski CO, Apostoleris NH. Predictors of parent involvement in children's schooling. $J$ Educ Psychol. 1997;89(3):538-548.

8. Desforges C, Abouchaar A. The impact of parental involvement, parental support and family education on pupil achievement and adjustment: a literature review. Research report No. 433. Nottingham: Department for Education and Skills; 2003.

9. Astone NM, McLanahan SS. Family structure, parental practices and high school completion. Am Sociol Rev. 1991;56(3):309-320.

10. Hoover-Dempsey KV, Sandler HM. Final Performance Report for OERI Grant \# R305T010673. The social context of parental involvement: A path to enhanced achievement. Washington: Institute of Educational Sciences; 2005.

11. McNeal RB. Parental Involvement as Social Capital: Differential Effectiveness on Science Achievement, Truancy, and Dropping Out. Soc Forces. 1999;78(1):117-144.

12. Bogenschneider K. Parental involvement in adolescent schooling: A proximal process with transcontextual validity. J Marriage Fam. 1997;59(3):718-733.

13. Deslandes R, Potvin P, Leclerc D. Family characteristics as predictors of school achievement: Parental involvement as a mediator. McGill Journal of Education. 1999;34(2):135-153.

14. Fan X, Chen M. Parental Involvement and Students' Academic Achievement: A Meta-Analysis. Educ Psychol Rev. 2001;13(1):1-22.

15. Gonzales-Pienda JA, Nunez JC, Gonzalez-Pumariega S, Alvarez L, Roces C, Garcia M. A structural equation model of parental involvement, motivational and aptitudinal characteristics, and academic achievement. J Exp Educ. 2002;70(3):257-287.

16. Jeynes WH. Effects of parental involvement and family structure on the academic achievement of adolescents. Marriage Fam Rev. 2005;37(3):99-116.
17. Okpala CO, Okpala AO, Smith FE. Parental involvement, instructional expenditures, family socioeconomic attributes, and student achievement. J Educ Res. 2001;95(2):110-115.

18. Rogers MA, Theule J, Ryan BA, Adams GR, Keating L. Parental Involvement and Children's School Achievement. Canadian Journal of School Psyhology. 2009;24(1):34-57.

19. Kim D, Rohner RP. Parental warmth, control, and involvement in schooling: Predicting academic achievement among Korean American adolescents. J Cross Cult Psychol. 2002;33(2):127-140.

20. Rohrbach LA, Hodgson CS, Broder BI, Montgomery SB, Flay BR, Hansen WB, et al. Parental Participation in Drug Abuse Prevention: Results From the Midwestern Prevention Project. J Res Adolescence. 1994;4(2):295-317.

21. Gecas V, Schwalbe ML. Parental Behavior and Adolescent Self-Esteem. J Marriage Fam. 1986; 48(1):37-46.

22. Finnegan RA, Hodges EV, Perry DG. Victimization by peers: Associations with children's reports of mother-child interaction. J Pers Soc Psychol. 1998;75(4):1076-1086.

23. Wasserman D, Carli V, Wasserman C, Apter A, Balazs J, Bobes J, et al. Saving and Empowering Young Lives in Europe (SEYLE): a randomized controlled trial. BMC Public Health. 2010;10:192-206.

24. Rozanov VA, Rakhimkulova AS, Ukhanova Al. «Life has no meaning» feelings in adolescents - relation to suicidal ideation and attemps and mental health. Suitsidologiya. 2014;5:33-40.

25. Ukhanova Al. The attitude to factors of healthy behavior in adolescents. Scientific Journal Virtus. 2017;14:55-60.

26. Ukhanova Al. Parental involvement as a factor of mental health of Ukrainian adolescents [Roditelskoe uchastie kak faktor psihicheskogo zdorovya ukrainskih podrostkov]. In: Proceedings of the G.S. Kostiuk Institute of Psyhology of National Pedagogical Sciences of Ukraine: Problems of General and Educational Psychology [Zbirnik naukovih prats Institutu psihologiyi Imeni G.S. Kostyuka NAPN Ukrayini: Aktualni problemi psihologiyi]. 2015;11(13):332-347.

27. Beck AT, Ward CH, Mendelson M, Mock J, Erbaugh J. An inventory for measuring depression. Arch Gen Psychiatry. 1961;4(6):561-571.

28. Evers SM. Health for All indicators in health interview surveys. Health Policy. 1993;23(3):205-218.

29. Young KS. Internet addiction: the emergence of a new clinical disorder. CyberPsychol Behav. 2009;1(3):237-244.

30. Baron RM, Kenny DA. The Moderator-Mediator Variable Distinction in Social Psychological Research: Conceptual, Strategic, and Statistical Considerations. J Pers Soc Psychol. 1986;51(6):1173-1182.

31. Holmbeck GN. Toward terminological, conceptual, and statistical clarity in the study of mediators and moderators: examples from the child-clinical and pediatric psychology literatures. J Consult Clin Psychol. 1997;65(4):599-610.

32. Lindley P, Walker SN. Theoretical and methodological differentiation of moderation and mediation. Nurs Res. 1993;42(5):276-279. 
33. Aldwin CM. Stress, coping, and development: an integrative perspective. New York: Guilford Press; 1994.

34. Hayes AF. Introduction to mediation, moderation, and conditional process analysis: a regression based approach. New York, London: The Guilford Press; 2013.

35. Gutsulyak L. The formation and development of school and family partnerships. History Pages. [Ctanovlennya y rozvitok partnerstva shkoli ta sim'yi (na prikladi Cpoluchenih Shtativ Ameriki). Storinki Istoriyi.]. Psychological-pedagogical problems of rural school [Psihologo-pedagogichni problemi silskoyi shkoli]. 2015;52:223-230.

36. Kovalchuk A. Characteristics autonomous school management in Western Europe [Harakteristiki avtonomnogo shkilnogo menedzhmentu v krayinah Zahyidnoyi Evropi]. Comparative-pedagogical studios [Porivnyal'nopedagogichni studii]. 2010;3-4:71-77.

37. Levin KA, Currie C. Adolescent toothbrushing and the home environment: sociodemographic factors, family relationships and mealtime routines and disorganization. Community Dent Oral Epidemiol. 2010;38(1):10-18.

38. Moreno C, Sánchez-Queija I, Mũnoz-Tinoco V, de Matos MG, Dallago L, Bogt TT, et al. Cross-national associations between parent and peer communication and psychological complaints. Int J Public Health. 2009;54(Suppl. 2):235-242.
39. Gerber M, Pühse U. “Don't crack under pressure!” - Do leisure time physical activity and self-esteem moderate the relationship between school-based stress and psychosomatic complaints? J Psychosom Res. 2008;65(4):363-369.

40. Flouri E, Buchanan A. The role of father involvement in children's later mental health. J Adolesc. 2003;26(1):6378.

41. Karvonen S, Vikat A, Rimpelä M. The role of school context in the increase in young people's health complaints in Finland. J Adolesc. 2005;28(1):1-16.

42. Kovacs M, Gatsonis C, Paulauskas SL, Richards C. Depressive disorders in childhood. IV. A longitudinal study of comorbidity with and risk for anxiety disorder. Arch Gen Psychiatry. 1989;46(9):776-782.

43. Balli SJ. When Mom and Dad Help: Student Reflections on Parent Involvement with Homework. Paper presented at: The Annual Meeting of the American Education Research Association; March 24-28, 1997; Chicago, IL.

44. Cooper H. Synthesis of research on homework. Educ Leadership. 1989;47(3):85-91.

45. Domina T. Leveling the Home Advantage: Assessing the Effectiveness of Parental Involvement in Elementary School. Sociol Educ. 2005;78(3):233-249. 


\section{UKLJUČENOST RODITELJA MODERIRA MEĐUSOBNU POVEZANOST STRESNIH DOGAĐAJA I MENTALNOG ZDRAVLJA ADOLESCENATA}

1 Odjel za kliničku psihologiju, Odessa I.I. Mechnikov National University.

\section{Sažetak}

Ovo je empirijsko transverzalno istraživanje osmišljeno kako bi se istražila potencijalna moderatorska uloga roditeljske uključenosti u interakciji između negativnih stresnih događaja u životu adolescenata i njihove psihološke dobrobiti. U sklopu švedsko-ukrajinske inicijative utemeljene na strategiji projekta SEYLE, ispitano je 589 učenika iz deset škola u Odessi. Prosječna je dob ispitanika 14,87 ( $\mathrm{SD}=1,11$ godina). Istraživanje je pokazalo da visoka razina roditeljske uključenosti ima zaštitnu ulogu u vezi s općim i mentalnim zdravljem, psihosomatskim poremećajima i ovisnosti o internetu kod ispitanika koji su izloženi različitim stresnim situacijama. No po pitanju nekoliko stresnih događaja, visoka razina roditeljske uključenosti ima negativan utjecaj. Točnije, to je uočeno u slučaju odlaska u zatvor $(\mathrm{F}=6,80 ; \mathrm{P}<0,01 ; \eta 2=0,01 ; \mathrm{B}=-0,93, \mathrm{Cl}$ $-1,64--0,23)$, prekršaja $(F=11,96 ; P<0,001 ; \eta 2=0,02$; $\mathrm{B}=-0,83, \mathrm{Cl}-1,30--0,36)$ i traumatske ozljede ili bolesti $(F=5,40 ; P<0,05 ; \eta 2=0,01 ; B=-0,54, C l-1,00--0,08)$. Stoga roditeljska uključenost općenito ima zaštitni utjecaj na mentalno zdravlje i psihološku dobrobit adolescenata u većini stresnih situacija. S druge strane, u nekim stresnim situacijama visoka razina roditeljske uključenosti može imati negativan utjecaj na dobrobit, vjerojatno zbog negativnih emocionalnih reakcija mladih u situacijama koje bi radije sakrili od svojih roditelja.
Ključne riječi: adolescenti, roditeljska uključenost, moderatorski utjecaj, negativni stresni događaji u životu, mentalno zdravlje 